Article

\title{
i-Yard 2.0: Integration of Sustainability into a Net-Zero Energy House
}

\author{
Yichun Jin, Junjie Li * and Wei Wu
}

School of Architecture and Design, Beijing Jiaotong University, Beijing 100044, China; 18121731@bjtu.edu.cn (Y.J.); 19121735@bjtu.edu.cn (W.W.)

* Correspondence: lijunjie@bjtu.edu.cn; Tel.: +86-10-18500234716; Fax: +86-10-62785691

Received: 21 April 2020; Accepted: 18 May 2020; Published: 20 May 2020

\begin{abstract}
This research introduces a residential net-zero energy house named i-Yard 2.0, which was built by a team from Beijing Jiaotong University for the 2018 Solar Decathlon China competition. The concept was based on the needs of an aging population and achieves energy self-sufficiency through both active (i.e., solar energy) and passive design strategies. With the growing recognition of the need for better environmental protection, green building strategies have become mainstream in building development. A building's energy balance is one of the most important indexes for assessing green buildings. The i-Yard 2.0 adopts an integrated design strategy with a sustainable development background. It takes a senior citizen-oriented design as the starting point and innovates in aspects such as community modeling, building strategies, passive spatial planning, the energy and building environment, and intelligent building control. The community comprises a new residential model called "cooperative living." The building strategy adopts a modular assembly approach in order to achieve rapid construction suitable for this type of competition. The passive spatial plan uses the notion of the courtyard as a green core to regulate the microclimate. The building environment achieves net-zero energy by improving active energy access and reducing passive energy consumption. The internet control model was designed to incorporate intelligent building control. The i-Yard 2.0 provides not only a new form of senior residential housing for developing areas, it also provides a novel and worthy reference for net-zero energy housing in China.
\end{abstract}

Keywords: net-zero energy house; building energy efficiency; green building; senior-oriented; solar decathlon competition

\section{Introduction}

Energy balance is one of the most important indexes for assessing green buildings [1]. After sustainable architectural design became mainstream in the world of building development [2], more and more projects began to consider, refer to, and even be based on green building evaluation. Among all of the green building evaluation indexes, building energy balance is one of the most intuitive, efficient, and recognizable [3]. Therefore, determining how to improve building energy balance is one of the first aspects to consider when engaging in green building design.

Improving active energy access and reducing passive energy consumption can improve building energy balance. Improving access to active energy [4] enhances efficiency through the use of solar panels, heat and light-shading louvers, and so on. Reducing passive energy consumption [5] reduces unnecessary daily energy loss via passive regulation courtyards, composite walls, etc. By increasing sources and reducing consumption, building energy balance can be improved.

The i-Yard 2.0 was Beijing Jiaotong University's entry in the 2018 Solar Decathlon China competition [6,7]. In terms of design, it is quite different from a passive house, low-energy house, and the nearly zero energy houses that can be seen in green buildings. For example, the "zero house" 
is a nearly zero energy house built in the suburbs of Beijing in 2019 [8]. Research on energy-saving strategies and design methods used in passive houses was published by Kai Liu and other Chinese scholars in 2020 [9]. The i-Yard 2.0 is a net-zero energy house that achieves energy self-sufficiency via solar energy [10]. The net-zero energy house uses renewable energy to completely supply the annual energy consumption of the building via a variety of active and passive designs and efficient energy savings equipment [11]. For example, the Aldo Leopold heritage center, built in the United States, realized net-zero energy consumption through a comprehensive strategic design [12]. A net-zero energy house can not only maximize energy consumption throughout the lifecycle of the building and achieve complete energy self-sufficiency, but also indirectly improve the ecological environment.

To address problems such as city population size, scarce resources, the environment, and China's aging population [13], the object market of the design was a senior residential house in a new town development. This was not a study of the net-zero energy design as applied to a type architecture, such as the 2020 work by Yu Zhang and other Chinese scholars who studied the development of an American net-zero energy structure that took the form of an education building [14]. Nor was it similar to the 2019 work by Jie Cheng and other Chinese scholars who studied the technology of net-zero energy houses in hot summer and cold winter regions [15]. Rather, the present work was based on China's increasingly acute population aging problem, and thus targeted a net-zero energy design for senior residential housing. The i-Yard 2.0 is quite specific in its design, and thus not entirely suitable for all types of residential housing.

"I-Yard 2.0," the name of the entry, is a continuation of the 2013 entry in the same competition. The " $\mathrm{i}$ " represents the " $3 \mathrm{i}$ " technology system-industrial, individual, and intelligent. Industrial construction and modular assembly can greatly reduce the construction cycle of net-zero energy houses, but this type of structure requires more thermal insulation and treatments to guarantee air-tightness at the junctions of building modules. For example, in 2018, AiSheng Wei and other Chinese scholars studied the thermal insulation and air-tightness of the joints of net-zero energy houses [16]. A variety of modular space combinations can meet different individual needs, breaking the homogeneity of traditional net-zero energy residential building spaces. Intelligent design provides a superior solution strategy for senior occupants and comprehensively improves the daily user experience of the elderly. "Yard" references China's traditional living space and history of enjoying life by returning to the garden and through self-care. In order to achieve the design objective of net-zero energy, the i-Yard 2.0, based on a senior-living building design [17], incorporated innovations in community modeling, building strategies, passive spatial planning, the energy and building environment, and intelligent building control. The i-Yard 2.0 serves as a new design concept for net-zero energy houses in new town developments.

\section{High-Performance Design Strategy}

\subsection{Community Model}

Due to China's aging society, being "senior" is becoming a general social phenomenon. In 2013, more than 200 million of China's population was over the age of $60,14.9 \%$ of the gross population. This phenomenon is expected to reach its peak by 2050. At that time, the aging population will be about 430 to 450 million, or one-third of the gross population [18]. Thus, research on the living environment is transforming from the traditional focus on architectural spatial functions to a greater emphasis on life order [19]. Conventional senior institutions and senior society models are being replaced by new paradigms [20] that show the diverse characteristics of the senior living environment.

The i-Yard 2.0 comprises a new residential model called "cooperative living" which is a continuation of the "senior cohousing" living model (see Figure 1), first developed in Denmark. Through free building, community residents combine traditional housing with shared public facilities, consciously participate in community design and management, and regularly organize public activities to enhance communication among residents [21]. This model has significantly influenced the American community 
to change to a cohabitation model. The cohabitation model enriches senior life, motivating a "senior cohousing" trend [22-24]. The German model of cohabitation constitutes a new neighborhood in which the elderly live with peers and nonpeers, enriching communication and encouraging shared lives [25].
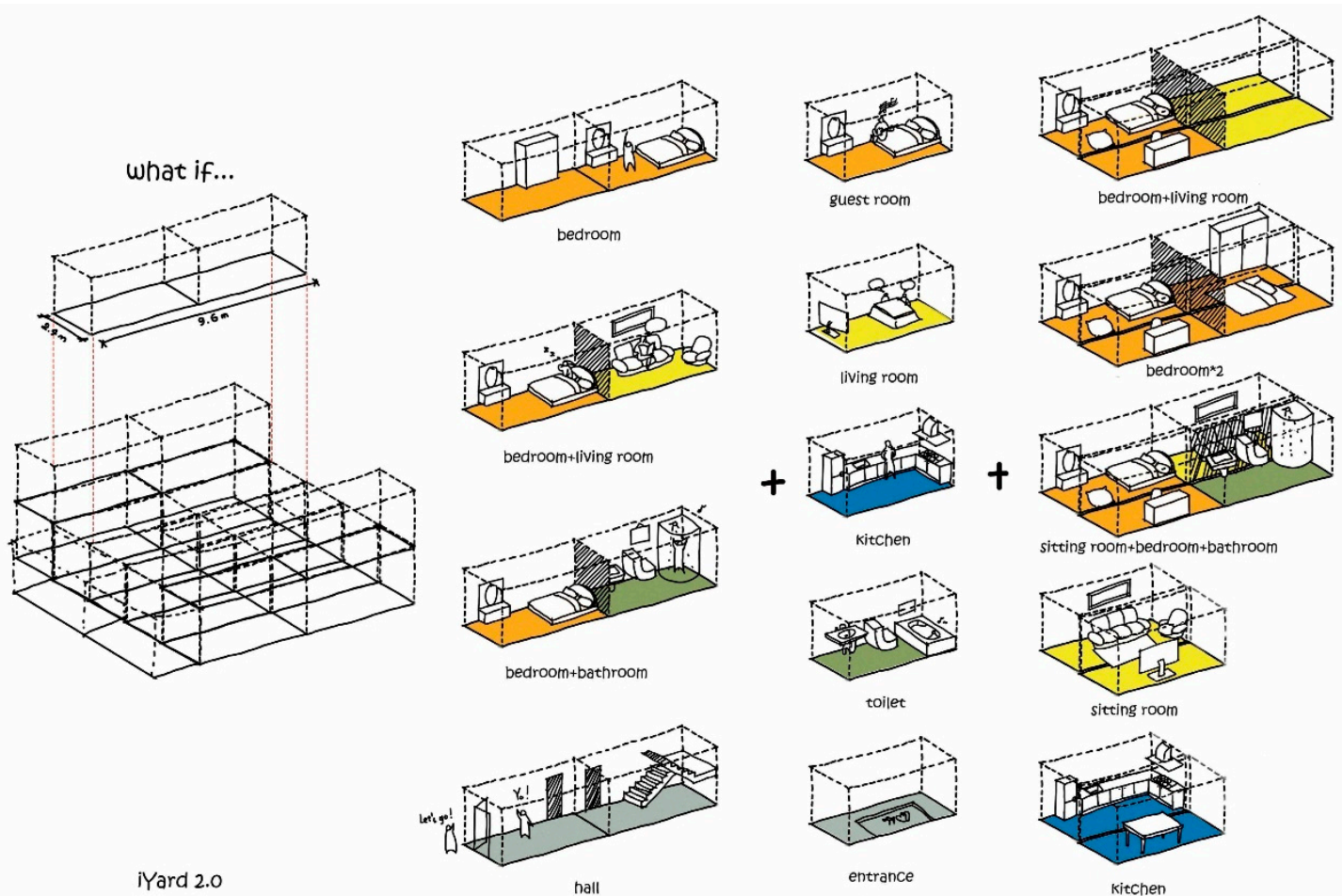

Figure 1. "Menu" for the independent customization model.

\subsection{Building Strategy}

\subsubsection{Response to the Rapid Construction Competition-Modular Assembly Strategy}

In order to meet the needs of construction efficiency and quality in new senior housing and conform to the potential for free combination, variable function, and multiple structures during a use cycle, the i-Yard 2.0 adopted a modular assembly construction strategy of heavy and light steel [26]. Modular assembly can greatly accelerate construction [27] to meet the exacting demands of a mere 23-day site construction schedule. During the 2018 Solar Decathlon China competition, the main building structure took only two days. On the first day, six boxes were built on the first floor. On the second day, three boxes were built on the second floor. The modular assembly strategy not only accelerates construction, but also reduces construction costs. For the i-Yard 2.0, the total construction cost was USD $\$ 218,700$, less than the average cost of NAHB (National Association of Home Builders) in 2013.

The i-Yard 2.0 was assembled from nine modules of the same size- $-9.6 \times 2.4 \mathrm{~m}$. The long side of each module was divided into two spans, each $4.8 \mathrm{~m}$. Therefore, from the view of module assembly, each side was a multiple of $2.4 \mathrm{~m}$, providing for the possibility of free assembly of the modules. The $2.4 \mathrm{~m}$ width is less than the standard size of a Chinese highway. Thus, after prefabrication, this type of module can be sent to construction sites at economical and reasonable transportation costs (see Figure 2). 


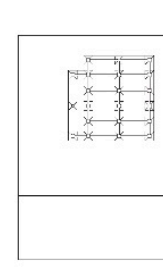

Foundation
Construction
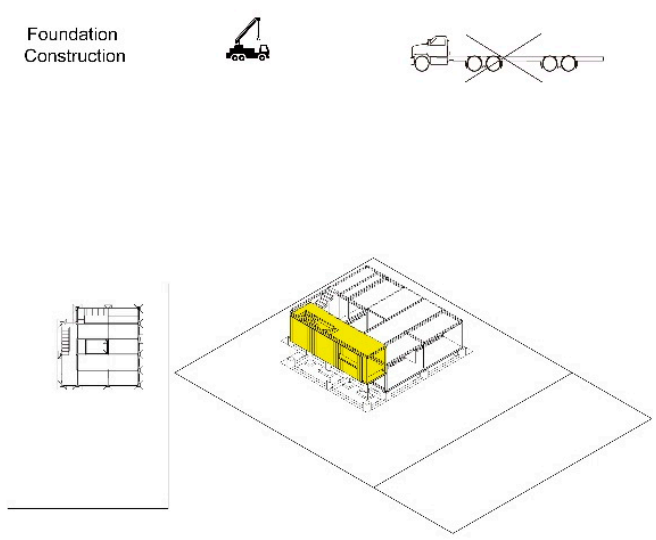

One Layer Vertical Module Installation
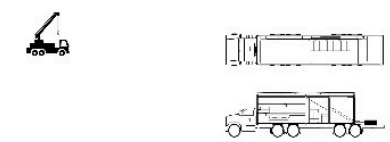
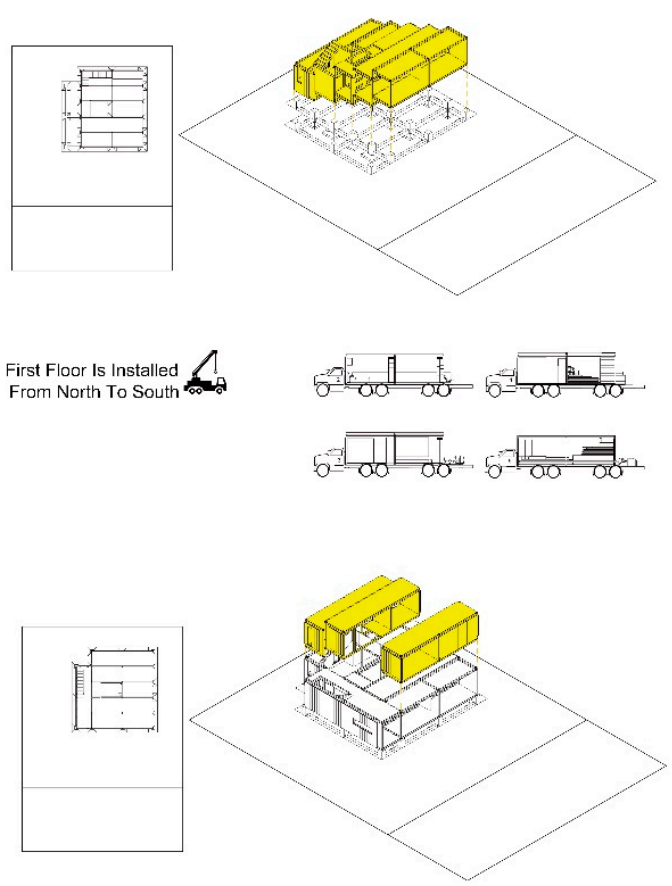

Two Layer
Module Installation

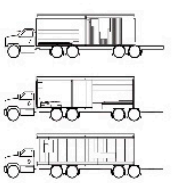

Figure 2. Modular assembly strategy for the i-Yard 2.0.

\subsubsection{Response to the Rapid Construction Competition— “Pin" Connection Method for Modules}

The modules depend on a "pin" connection method developed by the project team. Importantly, this allows for module connections to be both horizontal and vertical. The connection structure is comprised of a connection unit with a lifting lug serving as the connection node. The connection unit is used to connect prestressed screws. The lifting lugs at both ends of the connection unit are the end lifting lugs; the lifting lugs in the middle of the connection unit are the middle lifting lugs. The lifting lugs are of a hollow frame construction. Alignment connectors are set into the upper and lower sides of the lifting lugs, and screws pass between the alignment connectors. The screws between the connection units are connected to each other by nuts. The ends of the screws passing through the lower ends of the lifting lugs are fixed with embedded parts. The screws and nuts use prestressed screws and interconnect between the connection unit to provide prestrain [28]. The alignment connectors include a base plate connected to the lifting lugs. A cone-shaped positioning block is set in the base plate. On the base plate and positioning block, there is a through hole of a position and size relative to the through screw. The "pin" connection overcomes defects in prior work, providing a new connection between steel member modules that does not require welding. Advantages include a simple structure, reliable force transmission, and strong structural integrity. All of the connection workings are outside of the modules. The "pin" connection method was adopted to perfectly match with the interior decoration of the modules. Thus, the connection units focus on a design that integrates the structural connections for hoisting, connecting, bending, shear, and seismic designs. They also satisfy the positioning accuracy problem of modular assembly (see Figure 3). 

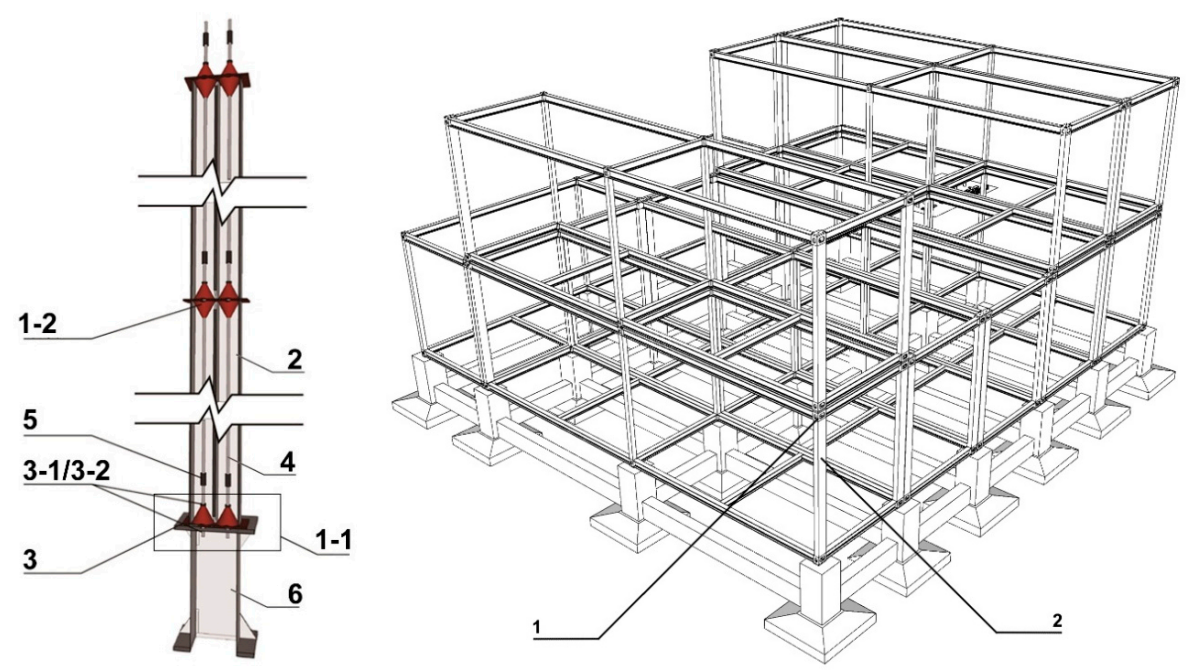

Figure 3. Structural module "pin" connection method. 1: lifting lug, 1-1: end lifting lug, 1-2: middle lifting lug, 1-3: void, 2: column, 3: alignment connector, 3-1: floor, 3-2: positioning block, 3-3: connection hole, 4: screw, 5: nuts, 6: embedded parts, 7: through hole.

\subsubsection{Response to Rapid Construction Competition-Rear-Mounted Integrated Composite Wall Panel}

The gap in the connection is the most decisive design node in the modular assembly. Not only is it crucial for building quality, it is also one of the most difficult issues to solve in modular buildings. Connections must be properly handled to prevent problems with waterproofing, insulation, and hot bridges, as well as improve air tightness. The i-Yard 2.0 uses a rear-mounted integrated composite wall panel construction method for model connection. The building's basic module is $600 \mathrm{~mm}$. After finishing the main frame assembly, an integration wall was added onto the outer wall. The integration wall incorporates a hitting technology that uses an OSB (Oriented Strand Board) as the structural base with aerogel felt attached. The waterproof permeable film is on the back of the OSB; this is also where the keel and trim were installed. After prefabrication of the integrated wall, the integrated wall panels were installed in the reserved pendant of the main steel beam structure and secured with self-tapping nails. This method integrates the structural, insulation, moisture-proofing, and decorative layers and is good for repeated disassembly, movement, and reassembly of buildings (see Figure 4).

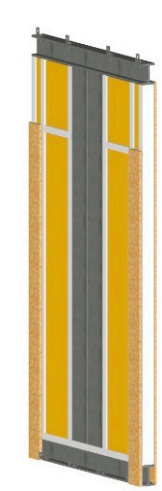

(1)

The foundation wall at
junction of two modules

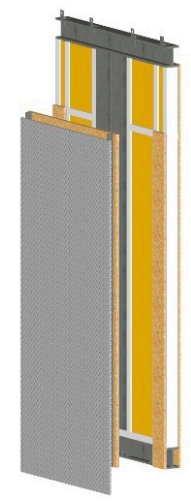

(2) Integrated wall including exterior
decoration, heat preservation
and structural plates
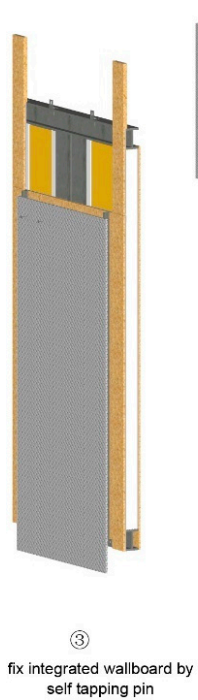
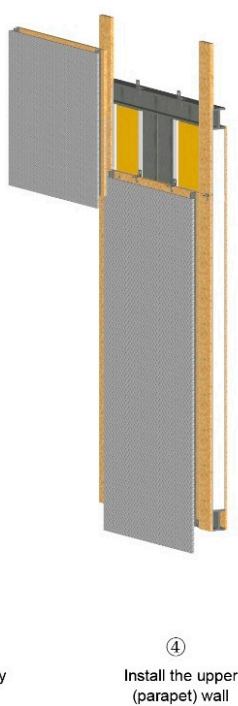

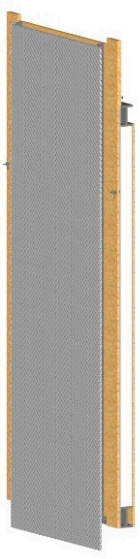

(5)

Figure 4. Installation of exterior wall panel with integrated finish, waterproofing, thermal insulation, and structure. 


\subsection{Passive Spatial Plan}

In order to improve the comfort of the building and health of the user, the i-Yard 2.0 adopted microclimate and microenvironment regulation as the main design strategy in the spatial plan of the building. Through this reasonable spatial plan, natural elements could be introduced into the interior to create a "country life" experience of returning to the pastoral. This climatic adaptation design is a response to the local environment [29]. It enables the building to make full use of the local climate conditions and dynamically adjusts and adapts to climate change to achieve function, comfort, and energy savings.

\subsubsection{Ternary Spatial Plan}

The i-Yard 2.0 is a two-story detached house $160 \mathrm{~m}^{2}$ in size, located in northern China. The inner space contains a living room, dining room, kitchen, three bedrooms, and two bathrooms. In the spatial plan, the sitting room, master bedroom, and study, all of which require sunshine, are located on the south side of building and form a strip of "living area." The auxiliary space (such as the courtyard) is located in the middle to regulate the microclimate. The kitchen and dining room are in the northern part of the building to form a strip of "service area." On the one hand, these rooms can use the sunshine and air brought in from the courtyard to adjust for thermal comfort [30]. On the other hand, these rooms block the northern cold wind in winter through service space such as an equipment room and staircase on the northernmost side. This spatial plan not only offers sunshine to those in the living space, it also improves the thermal insulation capacity of the building and reduces energy consumption during operation (see Figure 5).

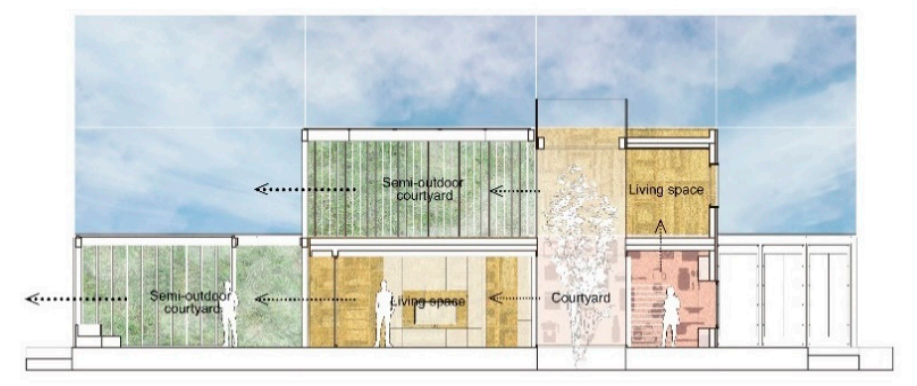

(a)

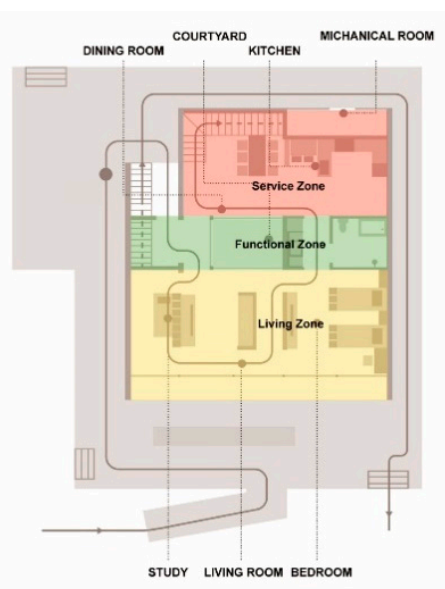

(b)

Figure 5. (a) Introduction of green ternary space; (b) ternary spatial plan for climate response.

\subsubsection{Green Core-Elevated Courtyard Combined with Passive Climate Regulation}

The courtyard is a key point of the i-Yard 2.0's design. It actually incorporates two types of courtyard. One is the inner courtyard, which is the green core of the courtyard. The other is the outer landscape gallery frame space. The size of the building's courtyard is $2.4 \times 3.2 \mathrm{~m}$. The platform of the courtyard, established through mechanical devices that borrow and modify the mechanical principles of a car parking system, can achieve the up-and-down movement of electric lifting to provide a "lifting floor," allowing for second-floor access without barriers for the elderly.

The courtyard platform is a floor with two layers of toughened glass embedded with $32 \mathrm{~mm}$ aerogel particles [31]. It offers good heat preservation, insulation, and light transmission [32]. According to the temporal and seasonal characteristics, the courtyard platform can regulate the heat gain and loss from solar radiation in the courtyard by changing the position of the movable floor in a vertical direction and thus adjusting the thermal environment inside the courtyard. The courtyard then forms a 
buffer zone between the indoors and outdoors to regulate the indoor light and heat environment, meet the requirements of human comfort, and reduce energy consumption during operation. On winter days, the floor is lowered to the bottom of the courtyard so that the it can receive full solar radiation. The illumination of the courtyard can be improved by using natural lighting, and the temperature can be increased by leveraging the greenhouse effect to fully absorb the heat of solar radiation. On winter nights, the floor can be raised to the middle of the courtyard (level with the second floor). The floor with heat preservation capacity is then converted into the building roof to reduce heat loss and store heat, maintaining the thermal environment of the courtyard. On summer days, the floor is raised to the middle of the courtyard (level with the second floor). The integrated floor has a shading design to block excessive solar radiation heat and prevent overheating of the courtyard. On summer nights, the floor is lowered to the bottom of the courtyard. The double-height space of the courtyard forms a "chimney effect" [33]. With the help of a window at the top, the courtyard forms hot pressure ventilation [34] and obtains a good passive cooling effect (see Figure 6).

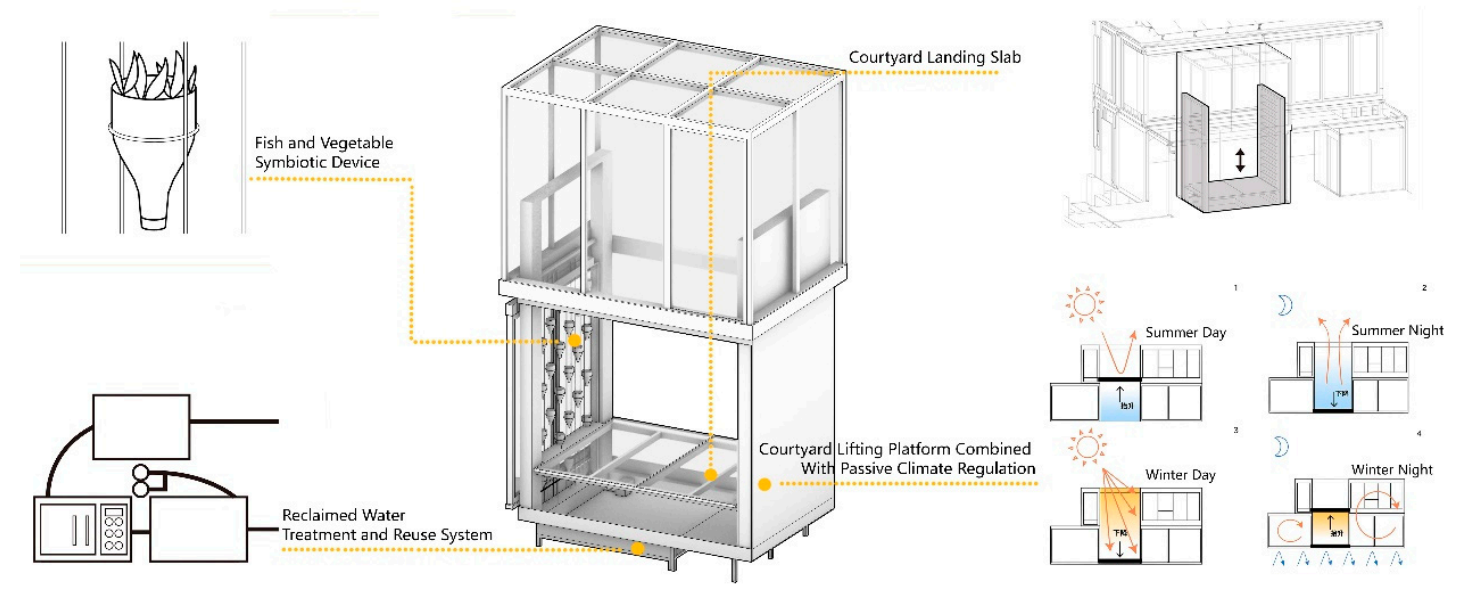

Figure 6. Elevated courtyard combined with passive climate regulation.

\subsubsection{Landscape Gallery Frame: Grey Space Placement}

The site is accessed from the south, but the entrance to the building is located on the north side. The best use of the southern sunshine is provided to the inner space. With the help of the landscape gallery frame on the west side, the grey space appears at the entrance of the building, enriching the outdoor courtyard landscape. The gallery space on the west side is combined with the vertical planting, enhancing the lives of the elderly inhabitants and allowing them to moderately participate in farming and planting. This offers a sense of returning to nature and an opportunity to socialize. The plants' greening affects air filtration, bringing healthier and more comfortable air to the indoor space [35]. Placement of the grey space on the west side effectively prevents intense solar radiation on that side in the summer. The grey space decreases heat gain on the west side of the building, improves indoor comfort, and reduces energy consumption (see Figure 7). 


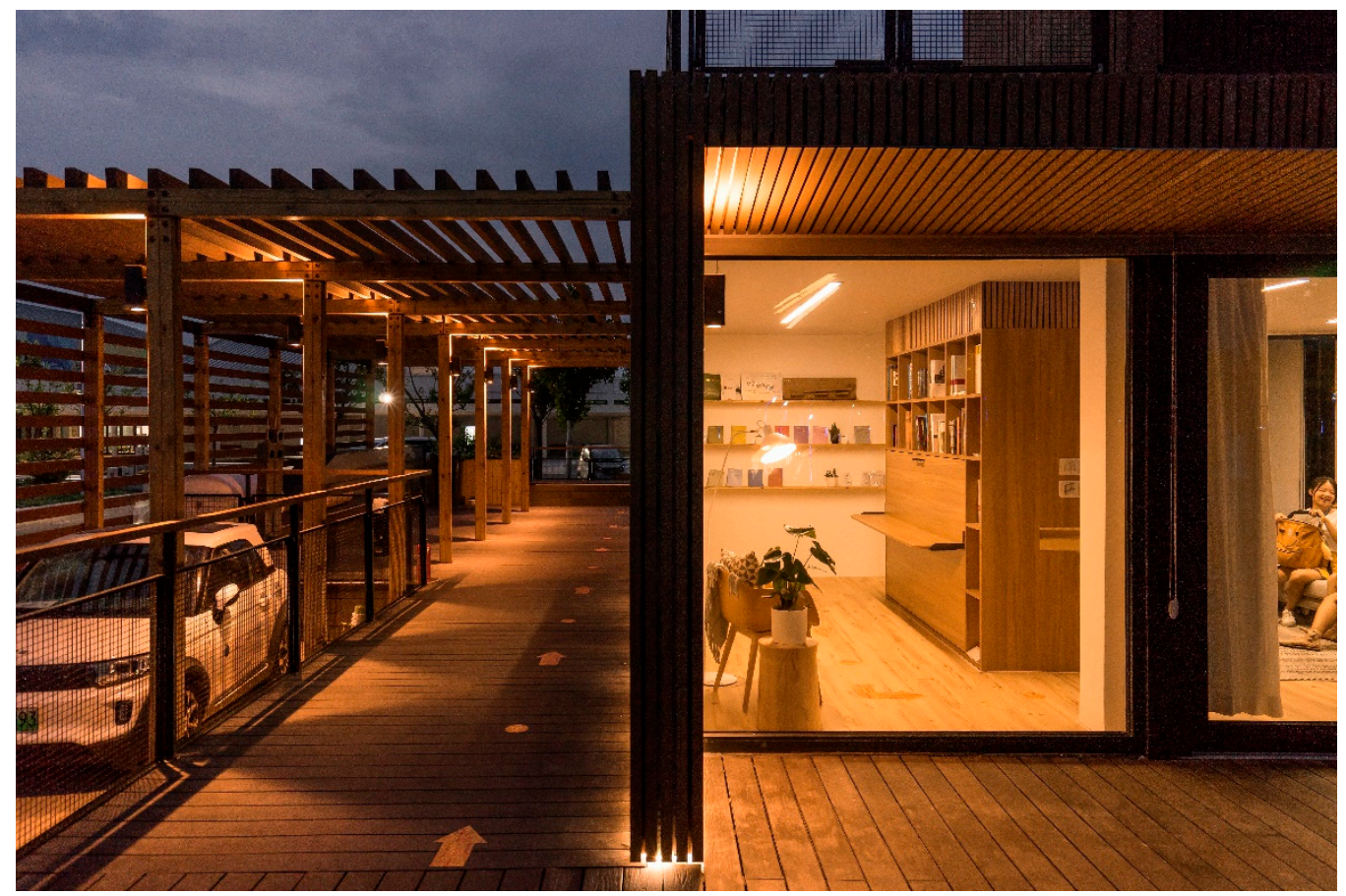

Figure 7. Landscape gallery frame on the west side of the building (actual photo).

\section{Energy and the Built Environment}

In order to improve energy use and the built environment, the i-Yard 2.0 adopted a series of active and passive strategies such as solar panels and a geothermal system. The end result was that the i-Yard 2.0 achieved net-zero energy consumption for an electromechanical equipment cost of USD $\$ 30,300$. This was higher than the average cost of NAHB (National Association of Home Builders) in 2013.

\subsection{Solar Energy Generation}

\subsubsection{N-Type Double-Sided Double Glass Photovoltaic Module}

Among the nine building modules of i-Yard 2.0, only three were laid with solar photovoltaic panels. These achieved complete energy self-sufficiency during the competition and won first place in the energy balance category. The photovoltaic power generation per square meter is a significant advantage (see Figure 8) [36]. The photovoltaic power system for the main double-sided body includes the photovoltaics as a smart energy solution. The N-type double-sided double-glass module (Jolywood, Taizhou, Suzhou, China) was selected for its high efficiency and excellent performance. The front-side efficiency is higher than $22 \%$, and the back-side efficiency is higher than $19 \%$. The module includes the advantages of no LID (Light Induced Degradation), low working temperature and temperature coefficient, and excellent weak light response (see Table 1) [37].

To maximize energy access as much as possible, the i-Yard 2.0's HVAC(Heating, Ventilation and Air Conditioning) system uses a photovoltaic direct-drive air conditioning system [38], further improving energy conversion efficiency and reducing energy consumption. 


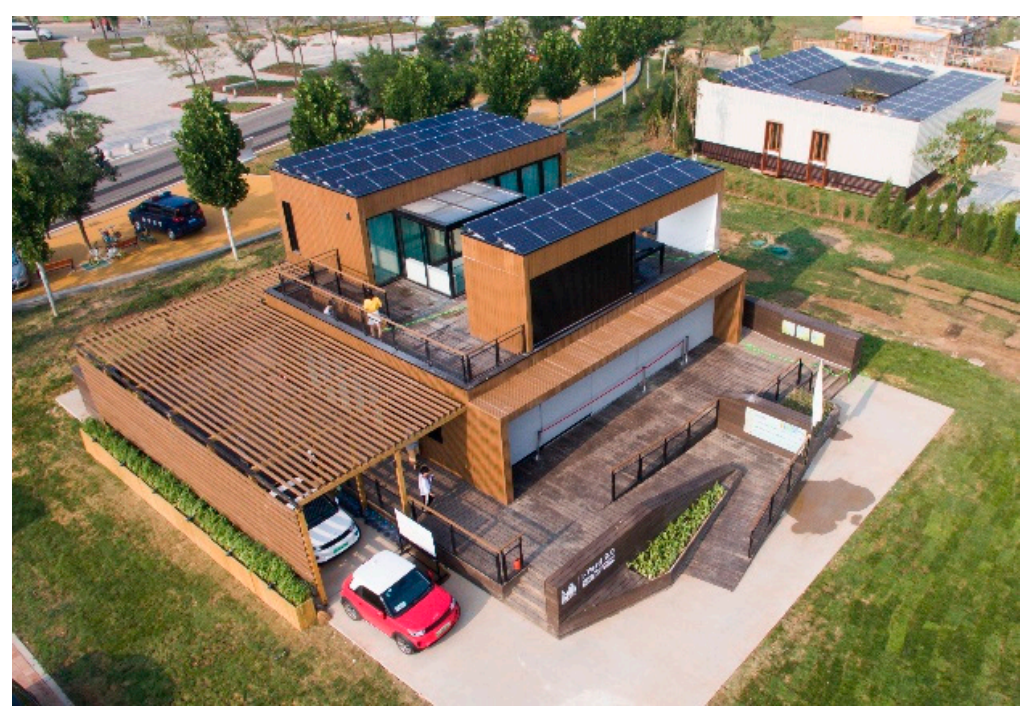

Figure 8. Rooftop solar photovoltaic and solar thermal panels.

Table 1. i-Yard 2.0 Photovoltaic System Parameters Table.

\begin{tabular}{cc}
\hline Item & Parameters \\
\hline Housing module size & $2400 \times 9600 \mathrm{~mm}$ \\
Basic size of single crystal & $156.75 \times 156.75 \mathrm{~mm}$ \\
Custom component size & $1182 \times 992 \mathrm{~mm}$ \\
Roof layer & $6 \times 9$ \\
Series and parallel & $27 \times 2$ \\
Effective area & $63.31 \mathrm{~m}^{2}$ \\
Comprehensive efficiency & $23.2 \%$ \\
Voc & $27.44 \mathrm{~V}$ \\
Vmmp & $22.61 \mathrm{~V}$ \\
Isc & $9.82 \mathrm{~A}$ \\
Current temperature coefficient & $0.048 \% / \mathrm{K}$ \\
Voltage temperature coefficient & $-0.30 \% / \mathrm{K}$ \\
Power temperature coefficient & $-0.38 \% / \mathrm{K}$ \\
\hline
\end{tabular}

\subsubsection{Sunshade Louver}

The sunroom in the high courtyard provides ample natural daylight and preheats the interior space in winter via solar radiation [39]. In summer, however, sunroom overheating is inevitable. Therefore, the top of the courtyard was designed with a set of sunshade louvers [40] combined with a solar thermal system (see Figure 9). The angle of the sunshade louver is favorable for blocking direct sunlight in summer and sending diffuse natural light into the room. At the end of each sunshade louver the heat medium pipe system of the solar thermal system is hidden to provide hot water sufficient for the entire building. During the competition, the i-Yard 2.0 scored full marks for the hot water item.

\subsubsection{Passive Solar Collector Air Wall}

A passive heat-collecting air wall was designed in the independent module located on the second floor on the south side of the building, using the principle of solar radiation in the winter [41] (see Figure 9). In winter, the black heat-collecting tube absorbs solar radiation to heat the air in the heat-collecting tube. Then, a fan is used to send the hot air directly into the living room below the module and achieve passive heating during winter days [42], saving on heating energy. The heat-collecting air wall can also be connected to the fresh air system to preheat the fresh air sent into the room and achieve the dual goals of indoor heating and air conditioning. 




Figure 9. South facade passive solar heat collector air wall.

\subsection{Building Energy Balance Test Results}

Based on the above building energy design strategy and in order to test the energy balance benefit of the building in the actual use stage, the i-Yard 2.0 team conducted convincing field, real, and energy efficiency tests and data collection, along with the help of the 2018 Solar Decathlon China competition. The i-Yard 2.0 won first place in the energy item in the final awards evaluation stage.

The solar system of the i-Yard 2.0 uses 36 custom photovoltaic modules (dimensions-1950 $\times$ $710 \mathrm{~mm}$ ). The photovoltaics' effective area is $49.82 \mathrm{~m}^{2}$, and the installed capacity is $9 \mathrm{KWp}$. Within 15 days of the competition's test time, the i-Yard 2.0 produced a total of $602.71 \mathrm{KWH}$ and consumed $573.23 \mathrm{KWH}$. This resulted in an energy balance of $+29.48 \mathrm{KWH}$. The efficiency of the photovoltaic power generation per square meter was $20.392 \mathrm{KWH} / \mathrm{m}^{2}$ at the time of the test, showing that complete net-zero energy consumption was achieved and resulting in building energy balance (see Table 2).

Table 2. Energy Balance Benefits.

\begin{tabular}{|c|c|c|c|}
\hline \multicolumn{4}{|c|}{ ENERGY } \\
\hline \multicolumn{4}{|c|}{ ENERGY BALANCE (80\%) } \\
\hline Date \& Time & Grid to House (E2) & House to Grid (E2) & Score Earned \\
\hline 2018-08-02 10:00:00 (Initial) & $621.03 \mathrm{kwh}$ & $81.42 \mathrm{kwh}$ & \\
\hline 2018-08-16 22:00:00 (Final) & $1194.26 \mathrm{kwh}$ & $684.13 \mathrm{kwh}$ & \\
\hline ENERGY BALANCE = (E2 & hal $\left.-\mathrm{E} 2_{\text {Initial }}\right)-\left(\mathrm{E} 2_{\text {Final }}-\right.$ & Initial $)=29.48 \mathrm{kwh}$ & 80.00 \\
\hline \multicolumn{4}{|c|}{ GENERATING CAPACITY (20\%) } \\
\hline Date \& Time & Power Generation (E3) & PV Area (A) & Score Earned \\
\hline 2018-08-02 10:00:00 (Initial) & $122.15 \mathrm{kwh}$ & $63.32 \mathrm{~m}^{2}$ & \\
\hline 2018-08-16 22:00:00 (Final) & $1413.38 \mathrm{kwh}$ & $63.32 \mathrm{~m}^{2}$ & \\
\hline $\begin{array}{r}\text { GENERATING CAPAC } \\
\text { Highest Generating }\end{array}$ & $\begin{array}{l}Y=\left(E 3_{\text {Final }}-\mathrm{E} 3_{\text {Initial }}\right) / \mathrm{A} \\
\text { Capacity among teams: } 2\end{array}$ & $\begin{array}{l}20.392 \mathrm{kwh} / \mathrm{m}^{2} \\
92 \mathrm{kwh} / \mathrm{m}^{2}\end{array}$ & 20.00 \\
\hline
\end{tabular}

\subsection{Building Comfort}

The i-Yard 2.0 has a relatively comprehensive design with regard to spatial comfort [43], regulating the internal building environment through an active system and passive spatial design [44,45]. The active design strategies targeting the indoor building environment include a geothermal system, photovoltaic direct-drive multiconnected air conditioner (Gree, Zhuhai, Guangdong, China), fresh air waste heat exchange system, etc. The passive design strategies include a heat-collecting air 
wall, variable atrium system, and others. The team for the Solar Decathlon China 2018 competition conducted field tests for indoor building environment comfort and recorded various indoor parameters during the 15-day competition, including indoor temperature and humidity and $\mathrm{CO}_{2}$ and PM2.5 concentrations $[46,47]$.

Indoor temperature was controlled at about 20 to $30^{\circ} \mathrm{C}$ during the competition. With the help of active regulation and passive cooling, the circulation system absorbs heat during the day and releases heat at night, maintaining a good indoor temperature environment [48] (see Figure 10).

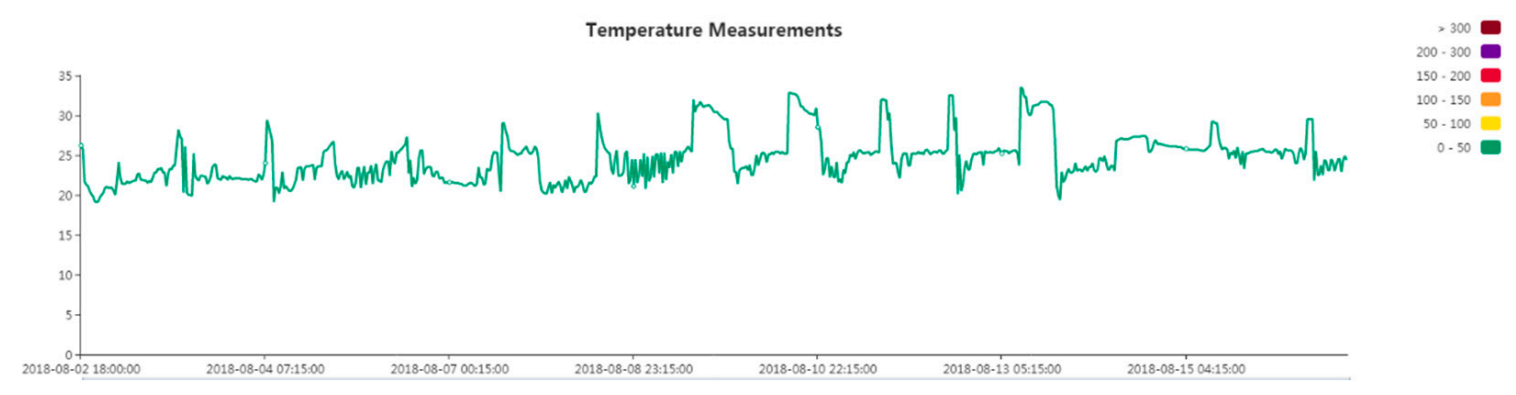

Figure 10. Indoor Temperature.

During the competition, the indoor humidity was controlled to $50 \%$ to $80 \%$ by the active fresh air system and passive regulation. Most of the time it was higher than $60 \%$, which is the human body's best comfort zone. Despite the extremely high outdoor humidity in summer, the variation range of indoor building humidity was relatively smooth and stable. The i-Yard 2.0 maintained a good indoor humidity environment (see Figure 11).

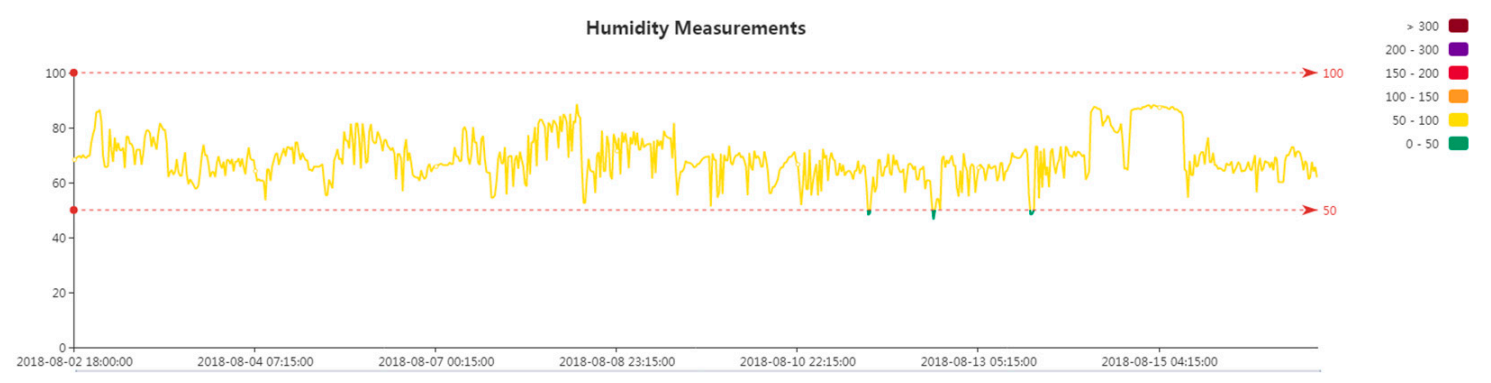

Figure 11. Indoor Humidity.

The $90 \%$ indoor $\mathrm{CO}_{2}$ concentration that the i-Yard 2.0 obtained during the competition was less than $1000 \mathrm{ppm}$, which is in the most comfortable range for the human body. Only about $10 \%$ of the time was the indoor $\mathrm{CO}_{2}$ concentration more than $1000 \mathrm{ppm}$ and less than $1200 \mathrm{ppm}$. The i-Yard 2.0 maintained a good indoor $\mathrm{CO}_{2}$ environment (see Figure 12).

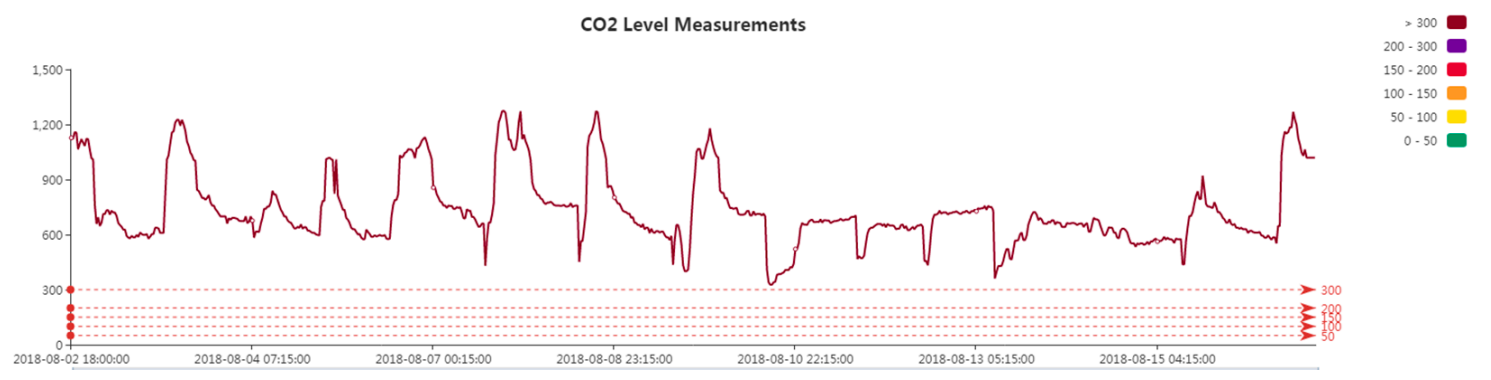

Figure 12. Indoor $\mathrm{CO}_{2}$ Concentration.

For $80 \%$ of the competition time, the indoor PM2.5 concentration for the i-Yard 2.0 was less than $35 \mathrm{ug} / \mathrm{m}^{3}$, which is in the best comfort zone. Only about $20 \%$ of the time was the concentration more 
than $35 \mathrm{ug} / \mathrm{m}^{3}$ and less than $50 \mathrm{ug} / \mathrm{m}^{3}$. The i-Yard 2.0 maintains a good indoor PM2.5 environment (see Figure 13).

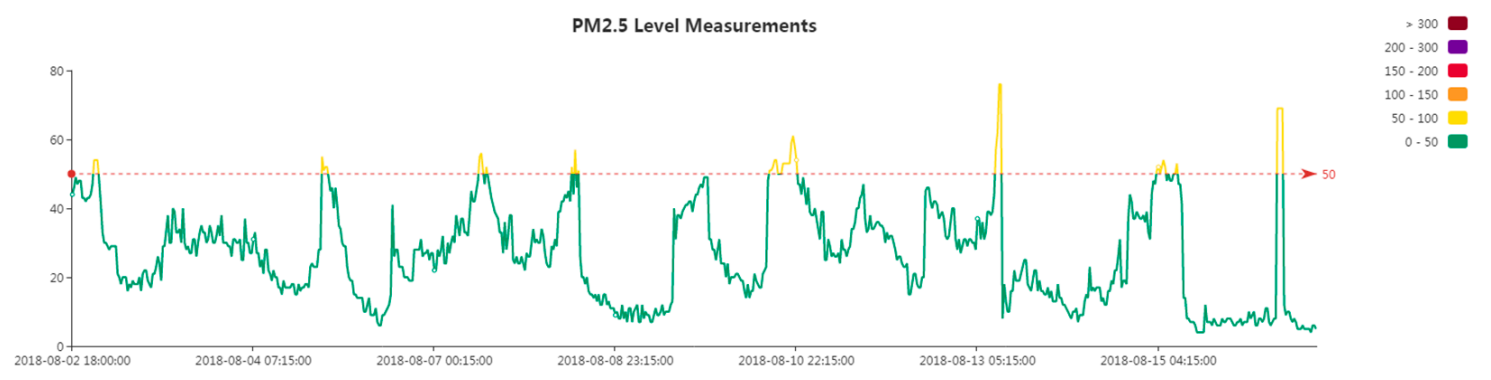

Figure 13. Indoor PM2.5 Concentration.

\section{Intelligent Building Control}

As the "blood" of building, the building system has a decisive influence on the quality of daily use. The building system is not a single system but rather the integration of several subsystems. Through the integration and coordination of each system, the overall stability and security of the system is achieved [49], creating a high-quality building environment.

\subsection{Safety Monitoring System}

Due to the decline in their physiology, the elderly often experience a decrease in mobility and ability to physically recover from injuries. Their bodies also become more vulnerable to other problems like sudden illnesses [50]. Thus, in this design, attention needed to be paid to the inhabitants' daily life and safety. Therefore, the i-Yard 2.0 team developed an intelligent app system that integrates a series of safety monitoring functions such as maintenance of occupants' physical condition and means of dealing with emergency situations. Information collected is transmitted to medical supervision, adult children, and outside peers by alarms, SMS messages, etc. The app includes systems for monitoring bodily condition and home positioning, as well as sounding emergency alarms [51]. All three systems acquire and transmit data through bracelets worn by the elderly occupants (see Figure 14).

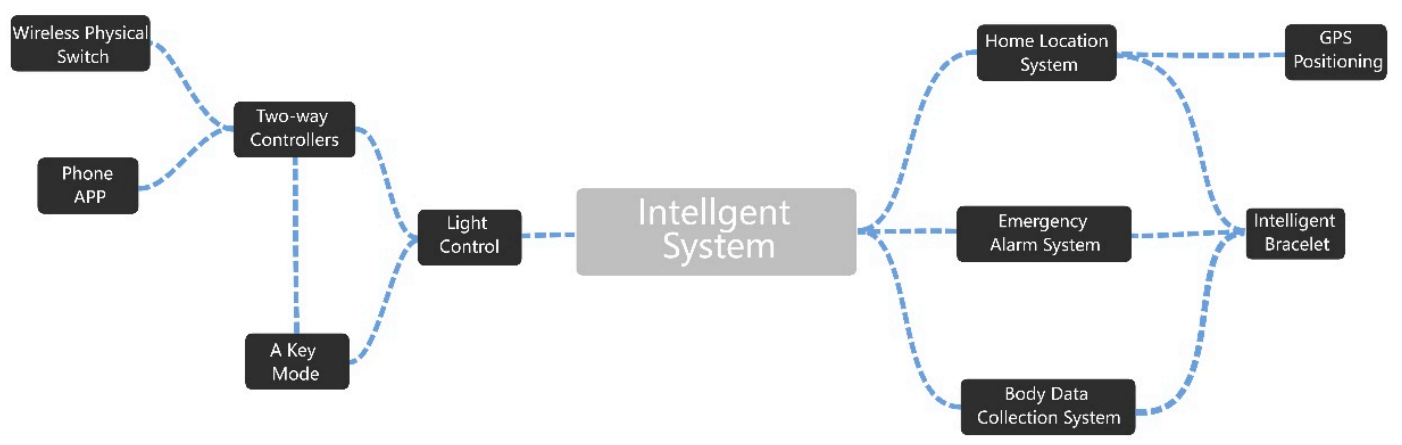

Figure 14. Schematic diagram of the intelligent control system.

\subsection{Environmental Control System}

The i-Yard 2.0 has a number of intelligent control systems based on a backflow line. There are infrared motion-sensing lights that provide safety to elderly occupants when they wake up at night, power rails to increase or decrease the number of outlets in each room according to need, and a long electric guide rail arranged at the head of each bed, making it convenient to add an oxygen supply, first aid system, monitoring equipment, and other first aid paraphernalia if the inhabitant should become bedridden [52]. The design also features the intelligent app, which makes it possible to control all indoor lighting via wireless physical switches, thus meeting the needs of users of all ages (see Figure 15). 

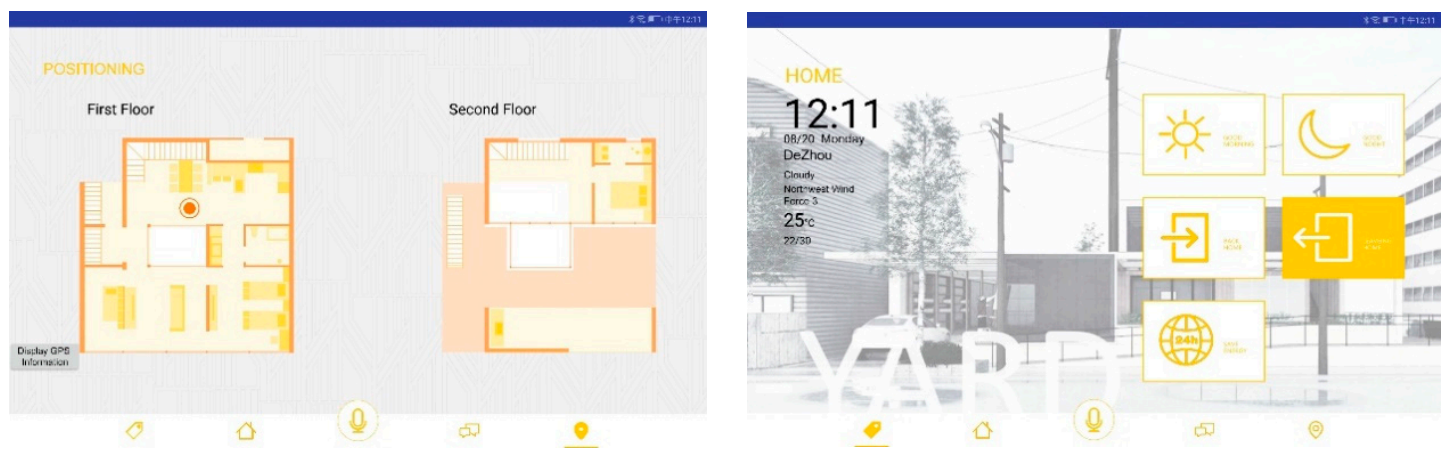

Figure 15. Intelligent app control and monitoring system.

\subsection{Psychological and Physical Care System}

The psychology of the elderly can gradually change, due to a decline in physiological function [53]. Weakening perceptions of the outside world, reduced ability and means to communicate, and children's long-term absence are all likely to make the elderly feel lonely [54]. At the same time, feelings of powerlessness may result in nostalgia for life when they were young. All of these changes require architectural designers to pay attention to the mental health of elderly occupants [55] to provide them with quality environments.

In the i-Yard 2.0, psychological and physiological care of the elderly are realized mainly through intelligent voice dialogue and living habits recognition systems that control indoor lighting, conduct health inspections, etc. The indoor lighting adjustment system uses a two-way control method to achieve remote control through a variety of wireless connection devices. Dual control is available through wireless physical switches and the intelligent app. By adjusting the light's brightness, color, temperature, one-key control mode, and nighttime wake-up sensing function, the internal light environment can best meet the psychological needs of the elderly in different user scenarios [56]. For example, it can set the lights to a warm color when the occupant is cooking in the kitchen. By enabling the one-click control mode, one can easily and quickly control all of the lights in the house when it is time to leave, arrive home, go to bed, and so on. At night, the light sensors protect elderly occupants' safety.

The lifestyle learning system uses intelligent control to simplify tedious tasks by learning daily routines, accumulating data, and gradually optimizing for the best experience. In consideration of the mobility and complex operation of smart panels, the intelligent voice dialogue system provides a convenient method of operation for older inhabitants. Occupants can speak into a mobile phone or face the intelligent control panel (the Kang Yang Magic Mirror located in the bathroom) to use voice control commands and achieve convenient home operation. Data on sleep quality, blood pressure, blood lipids, body weight, body fat, heart rate, body water content, cortex, tooth brushing, and other factors can be collected with the help of the Kang Yang Magic Mirror in the bathroom and other health monitoring systems, allowing for better health maintenance.

\section{Conclusions}

The residential i-Yard 2.0 was designed for senior living and features novel innovations in community model, construction method, spatial plan, energy efficiency, and smart building control. By improving active energy access and passive energy consumption, the i-Yard 2.0 was designed for energy balance. This was illustrated in a field test conducted during the 2018 Solar Decathlon competition, which showed that the i-Yard 2.0 realizes the goal of energy self-sufficiency and a net-zero house [57].

Therefore, if society seeks to promote the development of net-zero energy houses in new town developments, the novel design framework of the i-Yard 2.0 offers the following benefits: 
1. The modular assembly and rapid construction can shorten the construction cycle, reducing the energy and materials consumed in the process;

2. The reasonable passive building space design can improve the comfort level of the environment within the building space, indirectly reducing energy consumption;

3. A dynamic balance between energy acquisition and consumption can be achieved by improving active energy acquisition through techniques such as solar energy; and

4. The smart building control can reduce energy waste by more rationally and effectively regulating the daily operation of the entire building system based on different times and use modes.

The relatively high building cost limits the generalization of the i-Yard 2.0. Modular assembly can minimize the construction cycle, but also inevitably increases the building cost. Therefore, future research will focus on how to achieve relatively appropriate cost control with different materials according to the economic capacities of different users.

Author Contributions: The three authors have made different contributions to the article. Y.J. is one of the main designers of the i-Yard 2.0. He participated in the construction, and wrote and translated the article. J.L. is the main faculty adviser of the i-Yard 2.0, leading the team to complete the design and construction, and guiding the writing and translation of articles. W.W. is one of the participants of $\mathrm{i}$-Yard 2.0. He is mainly responsible for project publicity and participated in the construction as well as the translation of the article. All authors have read and agreed to the published version of the manuscript.

Funding: This work was supported by the National Natural Science Foundation of China (Grant No. 51708019) and the Fundamental Funds for Beijing Natural Science Foundation of China (Grant No. 8182043).

Conflicts of Interest: The authors declare no conflict of interest.

\section{References}

1. Jalaei, F.; Jalaei, F.; Mohammadi, S. An integrated BIM-LEED application to automate sustainable design assessment framework at the conceptual stage of building projects. Sustain. Cities Soc. 2020, 53, 101979. [CrossRef]

2. de Gaulmyn, C.; Dupre, K. Teaching sustainable design in architecture education: Critical review of Easy Approach for Sustainable and Environmental Design (EASED). Front. Architect. Res. 2019, 8, 238-260. [CrossRef]

3. Yang, Y. Comparative analysis of Chinese and American green building evaluation system. Build. Mater. Décor. 2019, 86-87.

4. Cho, H.I.; Cabrera, D.; Patel, M.K. Estimation of energy savings potential through hydraulic balancing of heating systems in buildings. J. Build. Eng. 2020, 28, 101030. [CrossRef]

5. Chen, X.; Huang, J.; Yang, H.; Peng, J. Approaching low-energy high-rise building by integrating passive architectural design with photovoltaic application. J. Clean. Prod. 2019, 220, 313-330. [CrossRef]

6. Navarro, I.; Gutiérrez, Á.; Montero, C.; Rodríguez-Ubinas, E.; Matallanas, E.; Castillo-Cagigal, M.; Porteros, M.; Solórzano, J.; Caamaño-Martín, E.; Egido, M.A.; et al. Experiences and methodology in a multidisciplinary energy and architecture competition: Solar Decathlon Europe 2012. Energy Build. 2014, 83, 3-9. [CrossRef]

7. Shrestha, P.P.; Mulepati, S. Energy Performance of a Solar Home Constructed for the Solar Decathlon Competition 2013. Procedia Eng. 2016, 145, 1298-1305. [CrossRef]

8. China's first "near zero energy" building has been completed in Beijing. Brick and Tile 2020, 2, 9.

9. Liu, K.; Sun, Y. Research on energy saving strategy and design method of passive house. Jiangxi Build. Mat. 2020, 4, 82-83.

10. Ascione, F.; Bianco, N.; Böttcher, O.; Kaltenbrunner, R.; Vanoli, G.P. Net zero-energy buildings in Germany: Design, model calibration and lessons learned from a case-study in Berlin. Energy Build. 2016, 133, 688-710. [CrossRef]

11. Liu, S.; Ma, X.B.; Yu, Y.Z. Development status and practice of zero energy building in the United States-A case study of bullitt center. Heating Vent. Air Cond. 2019, 49, 108-114.

12. Fan, A.; Peng, Z. The meaning of zero energy building-The inspiration from the aldo Leopold heritage center. Anhui Build. 2019, 26, 22-58. 
13. Cheng, Z.; Ma, J. The evolution of China's aging population and its countermeasures. Acad. Exch. 2018, 12, 101-109.

14. Zhang, Y.; Ren, L.; Tang, X. New development and enlightenment of "net zero energy" buildings in the United States-A case study of "net zero energy" buildings in education in the United States. World Archit. 2020, 3, 126-133.

15. Cheng, J.; Liu, S.; Wang, S.; Ma, X. Research on application and promotion model of zero-energy building technology in hot summer and warm winter areas. Constr. Technol. 2019, 24, 25-27.

16. Wei, A.; Zhang, T.; Jiang, F. Construction technology of heat preservation and airtight joints in net zero energy prefabricated buildings. Constr. Tech. 2018, 47, 1673-1676.

17. Dadzie, J.; Ding, G.; Runeson, G. Relationship between Sustainable Technology and Building Age: Evidence from Australia. Procedia Eng. 2017, 180, 1131-1138. [CrossRef]

18. Tang, J.; Kang, X.; Chen, R.; Gu, W. Research on functional spatial model and index system of comprehensive elderly care community. J. Urban Plan. 2015, 2, 83-92.

19. Yin, J.; Peng, Z. Active aging: The enlightenment of active retirement communities in the United States on the construction of retirement communities in China. Int. Urban Plan. 2017, 32, 125-131. [CrossRef]

20. Pak, T.-Y. Social protection for happiness? The impact of social senior reform on subjective well-being of the Korean elderly. J. Policy Model. 2020, 42, 349-366. [CrossRef]

21. Fang, M.; Luo, Y.; Qiu, B. Experience and enlightenment of developing housing cooperatives-Based on the model of western countries and China's preliminary practice. Urban Dev. Res. 2016, 23, 19-27.

22. Lu, F.; Xia, H. From physical space planning to public participation-On intelligent community planning based on spring hill cooperative ecological settlements. World Archit. 2015, 8, 124-131.

23. McCamant, K.; Durrett, C. Creating Senior Cohousing: Building Sustainable Communities; New Society Publishers: Gabriola Island, BC, Canada, 2011.

24. McCamant, M.; Durrett, C. Senior Cohousing: A Contemporary Approach to Housing Ourselves; Ten Speed Press: Berkeley, CA, USA, 1994; p. 12.

25. Sargisson, L. Fool's Gold? Utopianism in the Twenty-Frist Century; Palgrave Macmillan: London, UK, 2012.

26. Generalova, E.M.; Generalov, V.P.; Kuznetsova, A.A. Modular Buildings in Modern Construction. Procedia Eng. 2016, 153, 167-172. [CrossRef]

27. Wang, Z.; Pan, W. A hybrid coupled wall system with replaceable steel coupling beams for high-rise modular buildings. J. Build. Eng. 2020, 31, 101355. [CrossRef]

28. Fernández-Ruiz, M.A.; Moskaleva, A.; Gil-Martín, L.M.; Palomares, A.; Hernández-Montes, E. Design and form-finding of compression structures with prestressing tendons. Eng. Struct. 2019, 197, 109394. [CrossRef]

29. Osman, M.M.; Sevinc, H. Adaptation of climate-responsive building design strategies and resilience to climate change in the hot/arid region of Khartoum, Sudan. Sustain. Cities Soc. 2019, 47, 101429. [CrossRef]

30. Valinejadshoubi, M.; Heidari, S.; Zamani, P. The impact of temperature difference of the sunny and shady yards on the natural ventilation of the vernacular buildings. J. Build. Eng. 2019, 26, 100880. [CrossRef]

31. Patil, S.P.; Shendye, P.; Markert, B. Mechanical properties and behavior of glass fiber-reinforced silica aerogel nanocomposites: Insights from all-atom simulations. Scr. Mater. 2020, 177, 65-68. [CrossRef]

32. Chi, F.; Xu, L.; Peng, C. Integration of completely passive cooling and heating systems with daylighting function into courtyard building towards energy saving. Appl. Energy 2020, 266, 114865. [CrossRef]

33. Lim, H.; Seo, J.; Song, D.; Yoon, S.; Kim, J. Interaction Analysis of Countermeasures for the Stack Effect in a High-Rise Office Building. Build. Environ. 2019, 168, 106530. [CrossRef]

34. Li, A.; Gao, X.; Ren, T. Study on thermal pressure in a sloping underground tunnel under natural ventilation. Energy Build. 2017, 147, 200-209. [CrossRef]

35. Pettit, T.; Irga, P.J.; Abdo, P.; Torpy, F.R. Do the plants in functional green walls contribute to their ability to filter particulate matter? Build. Environ. 2017, 125, 299-307. [CrossRef]

36. Li, G.; Xuan, Q.; Akram, M.W.; Akhlaghi, Y.G.; Liu, H.; Shittu, S. Building integrated solar concentrating systems: A review. Appl. Energy 2020, 260, 114288. [CrossRef]

37. Jolywood (Taizhou) Solar Technology. N-type Bifacial High Efficiency Mono Silicon Double Glass Module. Available online: http://www.jolywood.cn/upload/202004/26/202004260928161729.pdf (accessed on 21 April 2020).

38. Asfour, O.S. A comparison between the daylighting and energy performance of courtyard and atrium buildings considering the hot climate of Saudi Arabia. J. Build. Eng. 2020, 30, 101299. [CrossRef] 
39. Chen, Y.; Liu, Y.; Wang, Y.; Wang, D.; Dong, Y. The Research on Solar Photovoltaic Direct-driven Air Conditioning System in Hot-humid Regions. Procedia Eng. 2017, 205, 1523-1538. [CrossRef]

40. Tao, Q.; Jiang, F.; Li, Z.; Zheng, J. A model of heat gain calculation for buildings with shuttle louvers: Verification and a case study. J. Build. Eng. 2019, 29, 101101. [CrossRef]

41. Chen, B.; Zhuang, Z.; Chen, X.; Jia, X. Field survey on indoor thermal environment of rural residences with coupled Chinese kang and passive solar collecting wall heating in Northeast China. Solar Energy 2006, 81, 781-790. [CrossRef]

42. Akaf, H.R.; Kohansal, M.E.; Moshari, S.; Gholami, J. A novel decision-making method for the prioritization of passive heating systems use; case study: Tehran. J. Build. Eng. 2019, 26, 100865. [CrossRef]

43. Acosta, I.; Campano, M.Á.; Molina, J.F. Window design in architecture: Analysis of energy savings for lighting and visual comfort in residential spaces. Appl. Energy 2016, 168, 493-506. [CrossRef]

44. Ginestet, S.; Aschan-Leygonie, C.; Bayeux, T.; Keirsbulck, M. Mould in indoor environments: The role of heating, ventilation and fuel poverty. A French perspective. Build. Environ. 2020, 169, 106577. [CrossRef]

45. Ren, J. Research on the Influence Factors of Energy Consumption and Indoor Comfort of Existing Residential Buildings in Cold Areas; Dalian University of Technology: Dalian, China, 2018.

46. Zhai, J.; Yu, J.; Kang, Y. Advances in research for underground buildings: Energy, thermal comfort and indoor air quality. Energy Build. 2020, 215, 109916.

47. Li, F. Research on Indoor Thermal Environment and Thermal Comfort of Residents in Nanjing Heating Houses; Nanjing Normal University: Nanjing, China, 2017.

48. Chandel, S.S.; Sharma, V.; Marwah, B.M. Review of energy efficient features in vernacular architecture for improving indoor thermal comfort conditions. Renew. Sustain. Energy Rev. 2016, 65, 459-477. [CrossRef]

49. Wang, Y.; Xu, Y.; Tang, Y. Distributed aggregation control of grid-interactive smart buildings for power system frequency support. Appl. Energy 2019, 251, 113371. [CrossRef]

50. Frumkin, K. Toppling Oranges: Death, Disability, Decline, and Readmission of Community-Dwelling Elderly Patients after an Emergency Department Visit. J. Emerg. Med. 2020, 58, 339-345. [CrossRef] [PubMed]

51. Huang, L.C.; Chang, H.C.; Chen, C.C.; Kuo, C.C. A ZigBee-based monitoring and protection system for building electrical safety. Energy Build. 2011, 43, 1418-1426. [CrossRef]

52. Dhakal, K.; Alsadoon, A.; Prasad PW, C.; Ali, R.S.; Pham, L.; Elchouemi, A. A novel solution for a Wireless Body Sensor Network: Telehealth elderly people monitoring. Egypt. Inform. J. 2019, in press. [CrossRef]

53. $\mathrm{Yu}, \mathrm{Q}$. Analysis on the status quo of mental health of elderly people in communities and nursing countermeasures. Modern Salt Chem. Ind. 2019, 46, 134-135.

54. Shen, Y. Discussion on related factors affecting mental health level of the elderly. World's Latest Med. Inf. Abstr. 2019, 19, 354-355.

55. Jing, Z.; Li, J.; Wang, Y.; Ding, L.; Tang, X.; Feng, Y.; Zhou, C. The mediating effect of psychological distress on cognitive function and physical frailty among the elderly: Evidence from rural Shandong, China. J. Affect. Disord. 2020, 268, 88-94. [CrossRef]

56. Wu, Y.; Liu, H.; Li, B.; Kosonen, R.; Kong, D.; Zhou, S.; Yao, R. Thermal adaptation of the elderly during summer in a hot humid area: Psychological, behavioral, and physiological responses. Energy Build. 2019, 203, 109450. [CrossRef]

57. Oki, R.; Tsuneoka, Y.; Yamaguchi, S.; Sugano, S.; Watanabe, N.; Akimoto, T.; Hayashi, Y.; Wakao, S.; Tanabe, S.-I. Renovating a house to aim for net-zero energy, thermal comfort, energy self-consumption and behavioural adaptation: A method proposed for ENEMANE HOUSE 2017. Energy Build. 2019, 201, 183-193. [CrossRef]

(C) 2020 by the authors. Licensee MDPI, Basel, Switzerland. This article is an open access article distributed under the terms and conditions of the Creative Commons Attribution (CC BY) license (http://creativecommons.org/licenses/by/4.0/). 